\title{
Preparation of Eco-friendly Antibacterial Silver Nanoparticles from Leaf Extract of Ficus Benjamina
}

\author{
Sara Zafar ${ }^{1}$, Asma Ashraf ${ }^{2}$, M. Yasin Ashraf*3, Farkhanda Asad ${ }^{2}$, Shagufta Perveen ${ }^{1}$, M. Amir Zafar ${ }^{1}$ and Andleeb \\ Shahzadi ${ }^{4}$
}

${ }^{1}$ Department of Botany, Govt. College University, Pakistan

${ }^{2}$ Department of Zoology, Govt. College University, Pakistan

${ }^{3}$ Nuclear Institute of Agriculture and Biology (NIAB), Pakistan

${ }^{4}$ Department Medical Pharmcology, Istanbul University, Turkey

Received: 制: September 29, 2018; Published: 制: October 04, 2018

*Corresponding author: M Yasin Ashraf, NIAB, Faisalabad, Pakistan

\begin{abstract}
Purpose: Present study was conducted to prepare simple, low cost and quick in action silver nanoparticles (Ag NPs) using silver nitrate and eco-friendly biological material (leaves of Ficus benjamina), for four pathogenic bacteria.

Methods: The leaf extract of Ficus benjamina was prepared by soaking $10 \mathrm{~g}$ washed leaves in $90 \mathrm{~mL}$ of distilled water and were boiled at $90{ }^{\circ} \mathrm{C}$ for 20 minutes; filtrate was stored at $4^{\circ} \mathrm{C}$. Silver nanoparticles were prepared by adding $10 \mathrm{~mL}$ of filtrate in $50 \mathrm{~mL}$ of $1 \mathrm{mM}$ silver nitrate solution, sonicated at $60^{\circ} \mathrm{C}$ for 60 minutes. A change in the color from yellow to brown indicated the formation of Ag NPs. Ag NPs were characterized by SEM, XRD and FTIR techniques and their antibacterial activity was estimated by disc diffusion method.

Results: The solution changed from a light yellowish to dark brown, caused by a reduction in the number of silver ions, confirming the synthesis of Ag NPs. The XRD spectrum revealed the crystalline Ag NPs were of $13.2 \mathrm{~nm}$ size. The FTIR and SEM images showed that the Ag NPs were fairly spherical. The disc-diffusion showed that prepared Ag NPs strongly inhibited the pathogenic activities of Bacillus subtilis, Pasteurella multocida, Staphylococcus aureus and Enterobacter aerogenes. The inhibition zone ranged from $7 \mathrm{~mm}$ to $13 \mathrm{~mm}$.
\end{abstract}

Conclusion: Present findings indicated that the green synthesis of Ag NPs has many advantages over other chemical procedures, offering enhanced safety, eco-friendlier and more superior in results.

Keywords: Biosynthesis of silver nanoparticles; Characterization; Antibacterial activity

Abbreviations: AgNPs: silver nanoparticles; XRD: X-Ray diffraction; SEM: scanning electron microscope; FTIR: Fourier Transform Infrared Spectroscopy

\section{Introduction}

Nanotechnology is an emerging field science having vast scope in research and development with the aim of production and implications of new materials having nanoscale dimension [1, 2]. Nanoparticles are atoms with size up to $100 \mathrm{~nm}$ [3] showing fascinating properties established on particular features such as size, utility and morphology. Characterization is performed to access different properties of the nanoparticles [4, 5]. Literature suggested a variety of nanoparticles utilization for different purposes like treatment of diseases and disorders but silver nano particles showed dominant antimicrobial activity $[1,6]$. They also have anti-inflammatory and anti-viral activity [7]. Silver is also used in silver-based ointments to cure wounds, burns and medical related strategies that are associated with polymers saturated with silver [8]. Utilization of silver (Ag) nanoparticles, particularly prepared with medicinal plants is a novel approach to treat microbial pathogen, furthermore, secondary metabolites in plant extracts play an important role in the synthesis of nano silver particles having strong antibacterial potential [9].

A large number of different protocols including chemical, physical and biological are used for the synthesis of nanoparticles $[10,11]$. By using different types of chemical procedures large number of nanoparticles can be prepared in short time, this method requires finishing agents for the stabilization of the size of the particles but non-toxic and environmentally friendly protocol is necessary for the formation of nanoparticles and to get rid of fatal chemicals as derivatives [12]. Plant extracts contain reducing and antioxidant properties which cause the reduction of metal salts to their respective nanoparticles [13]. Therefore, demand of green nanotechnology is increased [14-16]. In the current year, formation of $\mathrm{Ag}$ nanoparticles by applying green chemistry with 
natural reducing, capping and stabilizing agents become a major attention for researcher [17]. Green chemistry production method of nanoparticles is less costly and ecological save for large scale production [18]. This study explains the production of Ag NPs through bio-reduction method using Ficus benjamina leaf extract. Different types of phytochemical have been involved in reducing of silver ions in silver nitrate solution which lead to the formation of Ag NPs. Furthermore, synthesized silver- nanoparticles were checked with different analytical approaches and their antibacterial action was checked through the disc diffusion method.

\section{Material and Methods \\ Extraction of Plant}

The leaves of Ficus benjamina were washed with distilled water three times. Dried homogeneous $10 \mathrm{~g}$ leaves censored into many sections were soaked in $90 \mathrm{~mL}$ of distilled water. The leaves were kept boiling at $90{ }^{\circ} \mathrm{C}$ for 20 minutes, extract was collected and stored at $4{ }^{\circ} \mathrm{C}$.

\section{Preparation of Ag NPs}

Silver nanoparticles were prepared by adding $10 \mathrm{~mL}$ of filtrate in $50 \mathrm{ml}$ of $1 \mathrm{mM}$ silver nitrate solution [19]. Sonicate the solution at about $60{ }^{\circ} \mathrm{C}$ for 60 minutes. A change in the color from yellow (bright) to brown (darkish) indicated the formation of silver nanoparticles.

\section{Characterization}

The dimeter of crystalline silver nanoparticles (Ag NPs) was calculated by using the X-Ray diffraction by Scherrer's equation

$$
\mathrm{t}=\mathrm{k} \lambda / \mathrm{B} \cos \theta
$$

where, $\mathrm{K}=(0.92), \mathrm{t}=$ crystal size,$\lambda=\left(1.5418 \mathrm{~A}^{\circ}\right)$.

\section{SEM (Scanning Electron Microscope)}

The SEM (scanning electron microscope) was used for scanning the surface of sample. The chemical nature of silver synthesized nanoparticles to classify the biomolecules responsible for reduction was developed by Fourier Transform Infrared Spectroscopy (FTIR) technique using FTIR RX1-Perkin Elmer in the wavelength range $4000-400 \mathrm{~cm}^{-1}$.

\section{Antibacterial Potential}

The antibacterial activity of prepared silver nanoparticles (Ag NPs) was examined using Kirby-Bauer standard disc diffusion method [20]. The application of bacterial suspension (100 $\mu \mathrm{l})$ on the surface of a nutrient agar plate was done overnight. Antibacterial disc (Gentamicin) and different concentrations of Ag NPs 50, 100, $150,200 \mu \mathrm{l} /$ disc were placed on the agar plate. After incubation at $37^{\circ} \mathrm{C}$ for $24 \mathrm{~h}$, the inhibition zones were noticed around each disc.

\section{Results}

\section{XRD Analysis}

The XRD diffraction spectrum of the "green" Ag NPs expressed peaks at $2 \theta(32,595,46,555,54,815,57,605,66,575)$ equivalent to Ag (101), (111), (200), (202) and (220) planes of standard XRD. The The XRD design clearly explained that prepared Ag NPs possess a cubic crystalline structure [21]. The XRD parameters revealed a strong plane of $\mathrm{Ag}$ (101) and other weaker planes (Figure 1). The average size (13.2 nm) of the crystalline Ag NPs was confirmed by $\mathrm{X}$-ray diffraction.

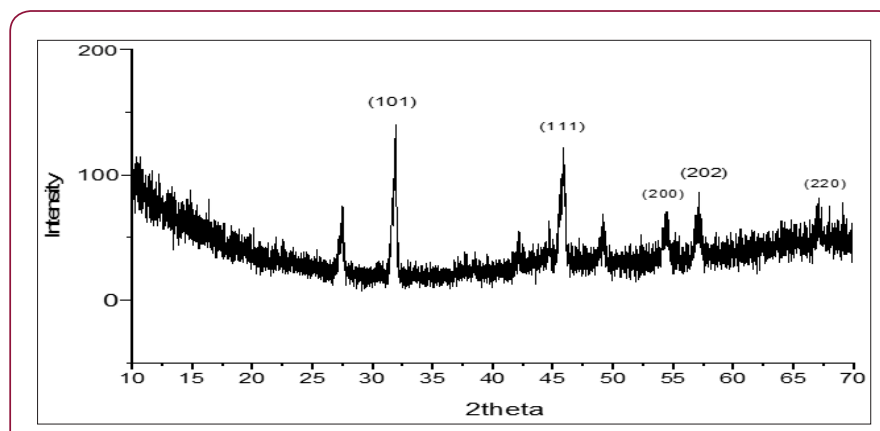

Figure 1: XRD patterns of silver nanoparticles using Ficus benjamina leaf extract.

\section{FTIR Analysis}

FTIR spectroscopy is an effective strategy for determining the major functional groups (reduced bio-molecules) necessary for the "green" synthesis of NPs via the reduction and stabilization of $\mathrm{Ag}^{+}$ ions (Figure 2). The FTIR spectrum revealed a number of absorption bands [22]. At $3405 \mathrm{~cm}^{-1}$ absorption band confirmed the presence of $\mathrm{O}-\mathrm{H}$ vibration of phenol, alcohol and phenol with stretching linkage of N-H of primary, secondary amides and amines (Table 1). Similarly, a peak at $2917 \mathrm{~cm}^{-1}$ was confirmed, representing stretching vibrations of methyl groups $(\mathrm{C}-\mathrm{H})$ [23]. The stretching sensations of peak at $1725 \mathrm{~cm}^{-1}$ showed the presence of $(\mathrm{C}=0)$ functional groups of carboxylic acids in addition with aldehydes and ketones. The carbonyl stretching absorption was found to be one of the strongest IR absorptions, and is a valuable component in terms of structure. A peak of Ag NPs was observed at band of $1592 \mathrm{~cm}^{-1}$, showing the occurance of N-H primary and secondary amides with amines, in addition to bending vibrations (Figure 2). A peak at 1369 $\mathrm{cm}^{-1}$ reflected bands of stretching of $\mathrm{C}-\mathrm{C}$ and $\mathrm{C}-\mathrm{N}$ groups, mostly present in proteins. Presence of alcohol and ether groups with $\mathrm{C}-\mathrm{O}$ streching vibrations was observed at the absorbing peak of 1020 $\mathrm{cm}^{-1}$ [24]. These biomolecules are responsible in the reduction (Ag ions) and stabilizing of the Ag NPs.

Table 1: FTIR result showed stretching and bending vibration of compounds with functional group.

\begin{tabular}{|c|c|c|c|}
\hline $\begin{array}{c}\text { Frequencies } \\
\mathbf{c m}^{-1}\end{array}$ & $\begin{array}{c}\text { Functional } \\
\text { group }\end{array}$ & Type of vibrations & Density \\
\hline 3405 & O_H, N_H & $\begin{array}{c}\text { H-bonded (alcohols, phenols), } \\
\text { Stretching (primary and } \\
\text { secondary amines \& amides) }\end{array}$ & M \\
\hline 2917 & C_H & $\begin{array}{c}\text { Stretch vibrations (methyl- } \\
\text { methyl \& methoxy) }\end{array}$ & S \\
\hline 1725 & C=O & $\begin{array}{c}\text { Stretch vibrations (aldehydes, } \\
\text { carboxylic acids \& ketones) }\end{array}$ & S \\
\hline 1592 & N_H & $\begin{array}{c}\text { Bend vibrations (primary and } \\
\text { secondary amines \& amides) }\end{array}$ & m s \\
\hline 1369 & C_C, C_N & Stretching vibration & S \\
\hline 1020 & C_O & $\begin{array}{r}\text { Stretch vibration (alcohols, } \\
\text { ether) }\end{array}$ & S \\
\hline
\end{tabular}






Figure 2: FTIR analysis of Ag NPs synthesized from Ficus benjamina leaf extract.

\section{SEM Analysis}

SEM analysis verified the presence of Ag NPs created by treating silver nitrate solution with Ficus benjamina leaf extract. The results revealed that the Ag NPs were mostly of uniform size $70 \mathrm{~nm}$ and fairly spherical. The shape and size of NPs are extremely dependent on the concentration of the leaf extract and the ratio of silver nitrate $\left(\mathrm{AgNO}_{3}\right)$ to Ficus benjamina extract (Figure 3).

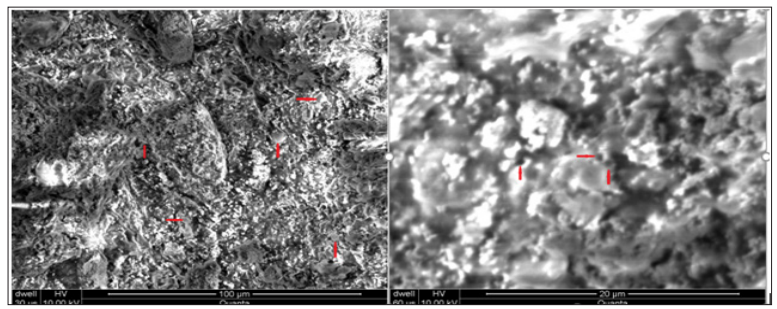

Figure 3: SEM images showing spherical Ag NPs with size of $70 \mathrm{~nm}$

\section{Antibacterial Potential}

Table 2: Ag NPs showed inhibiting activity against four pathogenic bacteria.

\begin{tabular}{|c|c|c|c|c|c|}
\hline \multirow{2}{*}{ Bacteria } & \multicolumn{5}{|c|}{ Inhibition zone against bacteria } \\
\cline { 2 - 6 } & Gentamicin & $\mathbf{5 0} \boldsymbol{\mu l}$ & $\mathbf{1 0 0} \boldsymbol{\mu l}$ & $\mathbf{1 5 0} \boldsymbol{\mu l}$ & $\mathbf{2 0 0} \boldsymbol{\mu l}$ \\
\hline $\begin{array}{c}\text { Enterobacter } \\
\text { aerogenes }\end{array}$ & $13 \mathbf{m m}$ & $7 \mathbf{m m}$ & $9 \mathbf{m m}$ & $11 \mathrm{~mm}$ & $\begin{array}{c}13 \\
\mathrm{~mm}\end{array}$ \\
\hline Pasteurella multocida & 13 & 8 & 9 & 12 & 13 \\
\hline Bacillus subtilis & 11 & 8 & 10 & 11 & 12 \\
\hline $\begin{array}{c}\text { Staphylococcus } \\
\text { aureus }\end{array}$ & 8 & 8 & 9 & 10 & 13 \\
\hline
\end{tabular}

The antibacterial activity of the synthesized Ag NPs was determined by disc-diffusion method. The nanoparticles expressed various level of antibacterial activity against two bacterial strains of Gram-positive bacteria (Bacillus subtilis, Staphylococcus aureus) and two strains of Gram-negative bacteria (Pasteurella multocida, Enterobacter aerogene,), depending on the diameter of the activity zone (Figure 4) and (Table 2). The antibacterial activity of Ag NPs differs by changing the concentration of the stock solution from 50 $\mu \mathrm{l}$ to $200 \mu \mathrm{l}$. With a solution of $200 \mu \mathrm{l} \mathrm{Ag} \mathrm{NPs}$ the highest growth inhibition effect of $13 \mathrm{~mm}$ was observed against Bacillus subtilis, Enterobacter aerogenes, Staphylococcus aureus and Pasteurella multocida (Figure 4) and (Table 2). The silver nanoparticles adhere to the negatively charged cell surface, and impair membrane permeability, osmoregulation, respiration and electron transport. The $\mathrm{Ag}^{+}$ions in silver nanoparticles lead directly to the denaturation of proteins in bacteria by bonding with sulfhydryl groups. Silver ions penetrate the cell wall and cause severe damage to the bacteria.

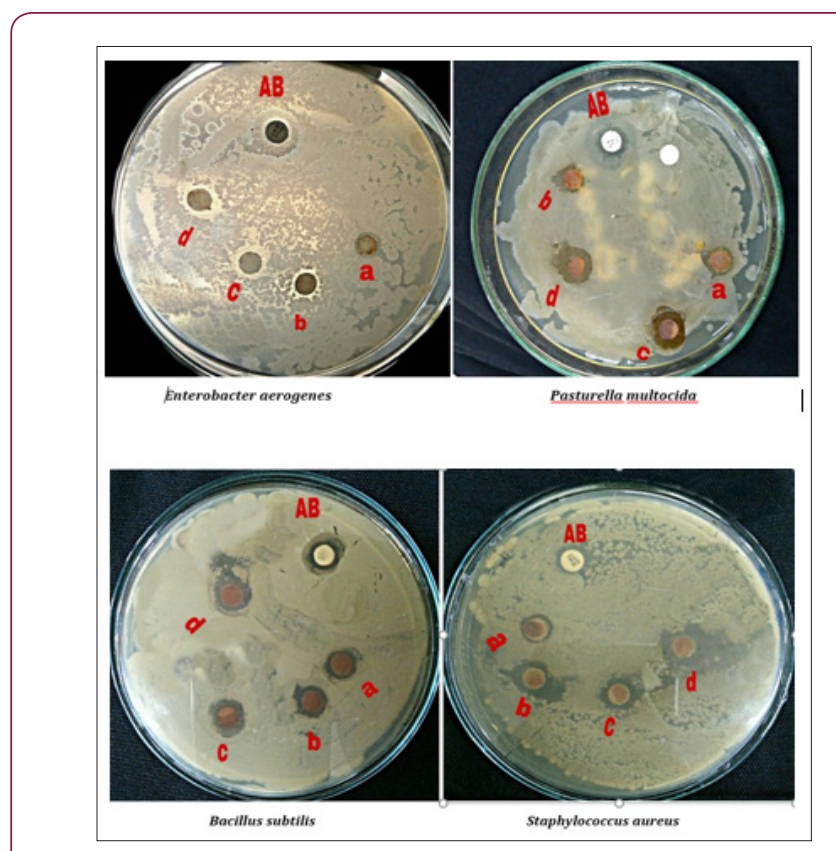

Figure 4: AB antibiotic (Gentamicin), a (50 ul), b (100 ul), c (150 ul), d (200 ul) Ag NPs.

\section{Discussion}

Ficus benjamina leaf extract was used for the preparation of $\mathrm{Ag}$ NPs because the bio-molecules in the leaf extract are effective in stabilizing the Ag NPs [21]. A change in color of the extract with $\mathrm{AgNO}_{3}$ solution indicated the reduction in silver ions that was due to the excitation of surface plasmon vibrations which confirmed the formation of Ag NPs [22]. Characterization of nanoparticles is necessary to know whether we prepared the desired nanoparticles for particular applications. By using XRD analysis formation of desired silver particles was determined and spectral analysis in different planes showed the nature of crystallization of particles and variations in their size and shape (Figure 1). Each Ag NP prepared with $13.2 \mathrm{~nm}$ average size exhibiting a crystalline structure in cubic form corresponding to $2 \theta$ values [21]. Biological molecules involved in stabilizing the Ag NPs were identified by FTIR dimension (Figure 2). The prominent peaks corresponded to the amines, alcohol, amide, phenol methyl and ether linkages (Figure 2). Other peaks suggested the existence of ketones, carboxylic acids and aldehydes [23]. The bending and stretching sensations revealed that bio-molecules like alcoholic groups, polyphenols, proteins and carboxylic acids are bound together by Ag NPs [24]. These nano molecules are inter connected with the reduction and controlling of $\mathrm{AgNO}_{3}$ and of the Ag particles.

SEM image analysis of surface morphology of nanoparticles revealed moderately spherical form with a diameter of $70 \mathrm{~nm}$ (Figure 3) as suggested in the literature [25]. Ficus benjamina leaf extract -mediated Ag NPs exhibited strong antibacterial activity. In 
this study, bacterial Gram-positive and Gram-negative strains were used to ascertain the inhibitory potential of Ag NPs and results showed that they had strong antibacterial activity and prepared Ag NPs varies according to the sizes of bacteria. Antibacterial activity increases with decreasing size of Ag NPs [26]. The findings of present study showed that the highest zone of inhibition of 13 mm with $200 \mu \mathrm{l}$ Ag NPs solution against Pasteurella multocida, Enterobacter aerogenes, Staphylococcus aureus and Bacillus subtilis (Figure 4) (Table 2). Ag NPs are capable of adhering and entering the the cell wall, causing changes in the membrane permeability leading to cell death [27]. Silver ions are absorbed by bacterial cells which inhibited normal cell functions and caused cell damage. The overall finding of presnt study illustrated that Ficus benjamina Ag NPs exhibited strong antibacterial activity against selected strains of pathogenic bacteria.

\section{Conclusion}

Present findings suggested that the green synthesis of Ag NPs has many advantages over other chemical procedures, offering enhanced safety, eco-friendlier and more superior in results. The characterization of Ag NPs was done through XRD spectra, showed that the Ag NPs are strongly dependent on the concentration of Ficus benjamina leaf extract and relative amount of silver nitrate to leaf extract. SEM descriptions revealed the Ag NPs were spherical in shape and FTIR analysis suggested that bio-molecules are involved in the silver ion reduction and in stabilizing Ag NPs. Green synthesized Ag NPs possess greater antibacterial activity against infectious bacteria illustrating an innovative way to a wide array of applications.

\section{References}

1. Kuchekar SR, Patil MP, Han SH (2015) Biosynthesis of silver nanoparticles using Nicotiana tobaccum leaf extract. World Pharm Sci 4: 1609-1616.

2. Agarwal H, Kumar SV, Rajeshkumar S (2017) A review on green synthesis of zinc oxide nanoparticles - An eco-friendly approach. Resour-Efficient Technol 3(4): 406-413.

3. Singh A, Dhaliwal H (2014) Green synthesis of silver nanoparticles using Phyllanthus niruri leaf extract and evaluation of their antimicrobial activities. Eur J Environ Ecol 2: 9-13.

4. Jain D, Daima HK, Kachhwaha S, Kothary SL (2009) Synthesis of plantmediated silver nanoparticles using papaya fruit extract and evaluation of their anti-microbial activities. Dig J Nanomater Biostruct 4: 557-563.

5. Vaishnav J, Subha V, Kirubanandan S, Arulmozhi M, Renganathan S(2017) Green synthesis of zinc oxide nanoparticles by Celosia argentea and its characterization. J Optoelectron Biomedicine Mater 9(1): 59-71.

6. Gong P, Li H, He X, Wang K, Jianbing Hu, et al. (2007) Preparation and antibacterial activity of $\mathrm{Fe}_{3} \mathrm{O}_{4} \mathrm{Ag}$ nanoparticles. Nanotechnol 18: 285604.

7. Veerasamy R, Xin TZ, Gunasagaran S, Terence Foo Wei Xiang, Eddy Fang Chou Yang, et al. (2011) Biosynthesis of silver nanoparticles using Mangosteen leaf extract and evaluation of their antimicrobial activities. J Saudi Chem Soc 15(2): 113-120.

8. Kim SH, Lee HS, Ryu DS, Choi SJ (2011) Antibacterial activity of silver nanoparticles against Staphylococcus aureus and Escherichia coli. J Microbiol Biotechnol 39: 77-85.

9. Chanda S (2014) Silver nanoparticles (medicinal plants mediated) a new generation of antimicrobials to combat microbial pathogens-a review.
Microbial Pathogens and Strategies for Combating Them: Science Technology and Education, ed. Mendez-Vilaz A (Formatex Research Center, Badajoz, Spain) 1314-1323.

10. Morones J, Elechiguerra JL, Camacho AHK, Holt K, Kouri JB, et al. (2005) The bactericidal effect of silver nanoparticles. Nanotechnol 16(10): 2346-2353.

11. Wei D, Sun W, Qian W, Yongzhong, Xiaoyuan Ma (2009) The synthesis of chitosan-based silver nanoparticles and their antibacterial activity. Carb Res 344(17): 2375-2382.

12. Singh A, Jain D, Upadhyay MK, Verma HN (2010) Green synthesis of silver nanoparticles using Argemone mexicana leaf extract and evaluation of their antimicrobial activities. Dig J Nanomater Biostruct 5(2): 483-489.

13. Saranya S, Eswari A, Gayathri E, Eswari S, Vijayarani K, (2017) Green synthesis of metallic nanoparticles using aqueous plant extract and their antibacterial activity. Int J Curr Microbiol Appl Sci 6(6): 1834-1845.

14. Shankar SS, Rai A, Ahmad A, Sastry M (2004) Rapid synthesis of Au, Ag, and bimetallic Au core-Ag shell nanoparticles using Neem (Azadirachta indica) leaf broth. J Colloid Interface Sci 275(2): 496-502.

15. Bar H, Bhui DH, Sahoo GP, Sarkar P, Sankar P De, et al. (2009) Green synthesis of silver nanoparticles using latex of (Jatropha curcas). Colloids Surf. A: Physicochem. Eng Asp 339(1-3): 134-139.

16. Geethalakshmi R, Sarada DVL (2010) Synthesis of plant-mediated silver nanoparticles using Trianthema decandra extract and evaluation of their anti-microbial activities. Intl J Eng Sci Technol 2: 970-975.

17. Ahmad A, Mukherjee P, Senapati S(2003) Extracellular biosynthesis of silver nanoparticles using the fungus Fusarium oxysporum. Colloids Surf B Biointerfaces 28(4): 313-318.

18. Jha AK, Prasad K, Prasad K, Kulkami AR, (2009) Plant system nature's nanofactory. Colloids Surf B Biointerfaces 73(2): 219-223.

19. Ajitha B, Reddy YAK, Reddy PS, Sunitha Y, Jin Jeon H, et al. (2016) Instant biosynthesis of silver nanoparticles using Lawsonia inermis leaf extract innate catalytic, antimicrobial and antioxidant activities. J Mol Liq 219: 474-481.

20. Velusamy P, Das J, Pachaiappan R, Vaseeharan B, Pandian K, (2015) Greener approach for synthesis of antibacterial silver nanoparticles using aqueous solution of neem gum (Azadirachta indica L.). Ind Crops Prod 66: 103-109.

21. Muthukrishnan S, Bhakya S, Kumar TS, Rao MV (2015) Biosynthesis, characterization and antibacterial effect of plant-mediated silver nanoparticles using Ceropegia thwaitesii-an endemic species. Ind Crops Prod 63: 119-124.

22. Sharma VK, Yngard RA, Lin Y (2009) Silver nanoparticles: green synthesis and their antimicrobial activities. Adv. Colloid Interface Sci 145(1-2): 83-96.

23. Shekhawat MS, Manokari M, Kannan N, Revathi J, Lalitha R (2013) Synthesis of silver nanoparticles using Cardiospermum halicacabum L. leaf extract and their characterization. J Phytopharmacol 2(5): 15-20.

24. Santhoshkumar T, Rahuman AA, Rajakumar G, Marimuthu S, Bagavan A, et al. (2011) Synthesis of silver nanoparticles using Nelumbo nucifera leaf extract and its larvicidal activity against malaria and filariasis vectors. J Parasitol Res 108(3): 693-702.

25. Ghaffari-Moghaddam M, Hadi-Dabanlou R (2014) Plant mediated green synthesis and antibacterial activity of silver nanoparticles using Crataegus douglasii fruit extract. J Ind Eng Chem 20(2): 739-744.

26. Guzman M, Dille J, Godet S (2012) Synthesis and antibacterial activity of silver nanoparticles against gram-positive and gram-negative bacteria. Nanomed Nanotechnol 8(1): 37-45.

27. Guzman MG, Dille J, Godet S (2009) Synthesis of silver nanoparticles by chemical reduction method and their antibacterial activity. Int J Chem Biomol Eng 2: 104-111. 
ISSN: 2574-1241

DOI: $10.26717 / B J S T R .2018 .09 .001829$

M Yasin Ashraf. Biomed J Sci \& Tech Res

(C) This work is licensed under Creative

Submission Link: https://biomedres.us/submit-manuscript.php

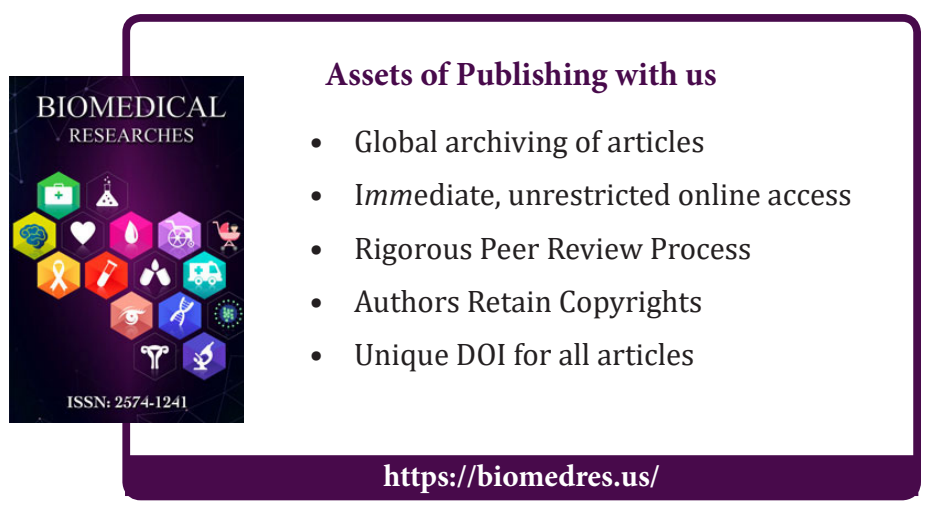

